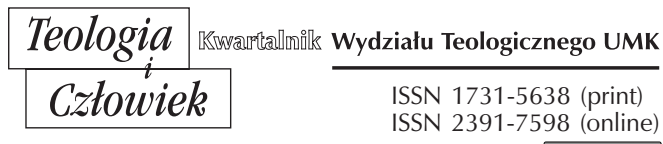

(c) (1) $\Theta$

53(2021)1, ss. 29-49

\title{
ZAUFANIE BOGU W ROZMYŚLANIACH DLA SIÓSTR URSZULANEK SERCA JEZUSA KONAJAZCEGO ŚW. URSZULI LEDÓCHOWSKIEJ
}

DOI: http://dx.doi.org/10.12775/TiCz.2021.002

Streszczenie. Artykuł przedstawia zagadnienie zaufania wobec Boga w pracy Rozmyślania św. Urszuli Ledóchowskiej (1865-1939), założycielki Zgromadzenia Sióstr Urszulanek Serca Jezusa Konającego. Według autorki Rozmyślań postawa zaufania bierze się ze świadomości bycia umiłowanym przez Boga, jest cechą charakterystyczną tego, kto żyje godnością dziecka Bożego. Człowiek dostrzegający swoją grzeszność, słabość i okazujący skruchę, może z ufnością uciekać się do Bożego miłosierdzia. Matka Ledóchowska - której duchowość cechuje się chrystocentryzmem - zachęca do zwracania się do Jezusa z całkowitym powierzaniem się w Jego ręce, zwłaszcza w trudnych sytuacjach. Zaufanie Bogu jest nieodzowne nie tylko w życiu zakonnym, lecz również w życiu każdego chrześcijanina.

Słowa kluczowe: zaufanie; Urszula Ledóchowska; rozmyślanie; duchowość.

\section{Abstract. Trust in God According to the Meditations of Saint Ursula} Ledóchowska. The article presents the issue of trust in God according to the Meditations of Saint Ursula Ledóchowska (1865-1939), the Foundress of the Congregation of the Ursuline Sisters of the Agonizing Heart of Jesus. According to the author of the Meditations, confidence comes from the awareness of being loved by God and is characteristic of those who live in the dignity of a child of God. A person who discerns their sinfulness and weakness and shows penitence can have complete confidence in the Divine 
Mercy. Mother Ursula Ledóchowska - with her Christocentric spirituality - encourages us to turn to Jesus and commit ourselves totally into His hands, especially in difficult situations. Trust in God is indispensable not only in monastic life, but also in the life of every Christian

Keywords: trust; Ursula Ledóchowska; meditation; spirituality.

\section{WSTĘP}

Ufność wobec Boga to fundamentalna postawa chrześcijańska, bez której nie sposób myśleć o autentycznej relacji z Bogiem. Święta Urszula Ledóchowska (1865-1939), założycielka Zgromadzenia Sióstr Urszulanek Serca Jezusa Konającego, podając różne zachęty, wskazania i napomnienia odnoszące się do życia duchowego, wielokrotnie przypomina o zaufaniu wobec Boga. Wezwanie do ufności powraca w jej wszystkich najważniejszych pismach, a szczególnie często występuje w dziele Rozmyślania. Rozmyślania są zbiorem medytacji i komentarzy do poszczególnych fragmentów Pisma Świętego (zwłaszcza Ewangelii), przeznaczonych do rozważania na każdy dzień roku. Według Matki Ledóchowskiej, stanowią - obok Konstytucji i Dyrektorium ${ }^{1}$ - jedno z najważniejszych jej pism pozostawionych dla Zgromadzenia przez nią założonego. Rozmyślania adresowane są do Sióstr Urszulanek Serca Jezusa Konającego, choć nie oznacza to, że wykluczają z grona odbiorców innych czytelników.

Niniejszy artykuł ma na celu ukazanie kwestii zaufania wobec Boga w dziele Rozmyślania św. Urszuli Ledóchowskiej. Warto zaznaczyć, że dotychczas nie powstały żadne publikacje podejmujące to zagadnienie. Kwestia ufności zostanie przedstawiona w czterech najważniejszych aspektach, o których pisze św. Urszula w danym dziele: ufność dziecka Bożego; zaufanie Chrystusowi i zupełne oddanie się w Jego ręce; ufność w miłosierdzie Boże oraz zaufanie w trudnych chwilach. Równocześnie zostanie pokazane, że - według autorki Rozmyślań - wszystkie te postawy są nieodzowne nie tylko w życiu zakonnym, lecz powinny charakteryzować również każdego chrześcijanina.

${ }^{1}$ Zob. U. Ledóchowska, Rozmyślania dla Sióstr Urszulanek Serca Jezusa Konajacego, t. 1, Pniewy 2000, s. 5. 


\section{UFNOŚĆ DZIECKA BOŻEGO}

Ufność wobec Boga to głębokie przeświadczenie, że należy $\mathrm{Mu}$ wierzyć i na Nim polegać. Jest to nadzieja pokładana w Bogu, realizująca się w konkretnej sytuacji. Ufność jest tym aspektem wiary, dzięki któremu - zwłaszcza w obliczu niepewnej przyszłości, słabości lub trudności - człowiek opiera się na Bogu jako na Tym, który nie może zawieść. Postawa ta to cecha człowieka wierzącego. Ufność jest tym silniejsza, im bardziej pokorna ${ }^{2}$. Święta Urszula akcentuje w Rozmyślaniach postawę zaufania, która przede wszystkim wypływa z faktu dziecięctwa Bożego.

Według Matki Ledóchowskiej postawa zaufania bierze się ze świadomości bycia umiłowanym przez Boga. Święta przypomina o znaczeniu godności dziecka Bożego: „Wszyscy byliśmy synami zatracenia, ale przyszedł Jezus, odkupił nas krwią swoją i staliśmy się dziećmi wielkiego Boga na niebie. Jaka to godność i łaska! Jakie to szczęście!”3. Zdaniem św. Urszuli tożsamość dziecka Bożego trzeba cenić bardziej niż jakiekolwiek inne przywileje na świecie. Tym, co czyni człowieka wielkim, jest miłość Boga, a nie honory, zaszczyty, pozycje społeczne i stanowiska. Matka stwierdza:

Żadnego szczęścia ziemi porównać nie można z tą łaską, żeśmy dziećmi Bożymi. Jestem dzieckiem Bożym - to znaczy, że Bóg, wielki Pan nieba i ziemi, jest mi Ojcem, jest mi Ojcem kochającym, nie surowym, nie twardym, lecz czułym do tego stopnia, że w Piśmie świętym tak do mnie się odzywa: „Choćby matka zapomnieć mogła o jednorodzonym synu swoim, ja o tobie nie zapomnę (zob. Iz 49,15 )"'.

Żywa świadomość bycia umiłowanym przez Boga jest fundamentem życia chrześcijańskiego.

„Serce moje potrzebuje wiedzieć, odczuwać, że ktoś je kocha” ${ }^{-}$ pisze Matka Urszula, dostrzegając podstawowe pragnienie każdego człowieka, które znajduje swoje wypełnienie w relacji do Boga. „Gdy podniosę oczy do góry, tam mam Ojca, który ciągle na mnie patrzy, ciągle o mnie myśli i ciągle mnie kocha! [...] Tyle w tej myśli znaleźć mogę odwagi

\footnotetext{
${ }^{2}$ Leksykon duchowości katolickiej, red. M. Chmielewski, Lublin-Kraków, s. 899.

${ }^{3}$ U. Ledóchowska, Rozmyślania, t. 1, XII 4. 1.

4 Tamże.

${ }^{5}$ Tamże.
} 
i ufności! Ojciec mój mnie kocha, Ojciec mój nigdy mnie nie opuści!”6. Doświadczenie miłości Boga Ojca nie może zostać zastąpione niczym innym. Właśnie to doświadczenie bycia nieskończenie i bezwarunkowo kochanym rodzi zaufanie wobec Boga. Święta Urszula pokazuje, że miłość Boga czeka na odpowiedź człowieka, pragnie być odwzajemniona. Chrześcijanin odpowiada Bogu przez miłość i zaufanie: „Miłość Boża domaga się od nas tej dziecięcej ufności, która tuli się do Boga jak do najlepszego Ojca i w Nim widzi najwierniejszego Przyjaciela; ufności, która nie zna bojaźni - bo bojaźń jest oznaką, że o sobie tylko myślimy - a żyje w miłości i miłością"7 - pisze autorka Rozmyślań, dotykając zarazem tego, co jest istotą chrześcijaństwa.

Według św. Urszuli postawa ufności wobec Boga jest właściwa dla relacji pomiędzy Stwórcą i stworzeniem. Człowiek, który wie, że zawdzięcza swoje istnienie Bogu, jest przekonany o swej zależności wobec Wszechmogącego i świadomy tego, że najlepiej jest powierzyć się Jemu z zaufaniem. „Bóg, On Mistrz i Stwórca nasz. A człowiek - to biedne, nędzne Jego stworzenie - cóż innego może czynić, jak nie oddać się w Jego ręce w najgłębszej pokorze serca, $\mathrm{z}$ ufnością bez granic, $\mathrm{z}$ uległością dziecięcą!" - pisze Matka Ledóchowska. Człowiek pełen zaufania wobec Boga jest więc prawdziwie pokorny. Według św. Urszuli osoba pokorna to ta, która patrzy w prawdzie: z jednej strony dostrzega wielkość i wszechmoc Boga, a z drugiej - swoją ograniczoność i nicość. Autorka Rozmyślań podkreśla oba te elementy, a ponadto integruje je ze sobą: widzi małość człowieka właśnie w świetle wielkości i wspaniałości Stwórcy. Ukazuje tę prawdę o znikomości osoby ludzkiej i pokazuje konieczność utrwalenia w sobie przeświadczenia o własnej nicości względem Nieskończonego Boga, co chroni człowieka przed pychą. Pisze:

Chcę w sobie wyrobić tak głębokie przekonanie o mej nicości, żeby cała moja istota była nim przejęta, żebym inaczej nie umiała myśleć o sobie i tylko to jedno przekonanie miała: jam nicością. To głębokie przeświadczenie o swej nicości muszę w sobie wyrabiać powoli, ale wytrwale,

${ }^{6}$ Tamże.

7 U. Ledóchowska, Rozmyślania, t. 1, XII 27. 2.

8 Taż, Rozmyślania dla Sióstr Urszulanek Serca Jezusa Konającego, t. 2, Pniewy 2000, VII 26. 1. 
rozmyślając często, bardzo często o swej nicości i korząc się głęboko przed Bogiem?

Człowiek pokorny posiada świadomość swej kruchości i ograniczoności, opartą nie tylko na chwilowym uczuciu, lecz na racjach rozumu ujmującego prawdę ${ }^{10}$. Matka Urszula pokazuje ścisły związek pokory z zaufaniem: „Pokorny spoczywa w Bogu, któremu z całą ufnością się oddaje. Wie, że sam nic nie potrafi, nic nie może, bo jest nicością, więc wszystkiego się spodziewa od źródła wszelkiego dobra, od swojego Boga, i we wszystkim na Nim polega"11. Zaufanie Bogu jest jednym z przejawów prawdziwej pokory.

Święta Urszula wskazuje na wzór zaufania: postawę Chrystusa wobec Ojca Niebieskiego. Jako przykłady podaje wiele ewangelicznych wydarzeń, m. in. wskazuje na sytuację, kiedy Jezus podczas burzy śpi w łodzi (Mt 8, 23-27). Autorka Rozmyślań rozważa tę scenę i komentuje ją następująco:

Jak spokojnie śpi Jezus wśród grożącego niebezpieczeństwa. Czy nie daje mi przez to przykładu, jak i ja powinnam zawsze spokojnie i z ufnością spoczywać na łonie woli Bożej, choćbym była otoczona niebezpieczeństwami i nieprzyjaciółmi? Niech dusza moja nigdy niczego się nie boi, bo Bóg mój, Ojciec mój, Pan mój, zawsze nade mną czuwa ${ }^{12}$.

Matka Ledóchowska pokazuje, że wzór zaufania wobec Ojca Niebieskiego znajduje się w Osobie Chrystusa, Syna Bożego. W Niego każdy wierzący powinien się wpatrywać, prosząc o łaskę naśladowania Zbawiciela i potrzebną moc Ducha Świętego.

\section{ZAUFANIE JEZUSOWI CHRYSTUSOWI I ODDANIE SIĘ W JEGO RĘCE}

Postawa zaufania Bogu jest zarazem zwróceniem się do Jezusa Chrystusa, który poprzez swoje zmartwychwstanie pokonał śmierć i chce wszystkich doprowadzić do zbawienia oraz szczęścia wiecznego. Matka Urszula -

9 Tamże, XI 12. 3.

10 Zob. M. Pagacz, Pokora w „Rozmyślaniach” św. Urszuli Ledóchowskiej w świetle „Ćwiczeń duchowych” św. Ignacego Loyoli, „Studia Bobolanum” 2(2019), s. $70-71$.

${ }^{11}$ U. Ledóchowska, Rozmyślania, t. 2, VI 19. 2.

12 Tamże, VII 13. 1. 
której duchowość charakteryzuje chrystocentryzm ${ }^{13}$ - wskazuje, że tym, co powinno napełniać wierzącego ufnością jest pewność dobroci Jezusa ${ }^{14}$ :

Nigdy, o Jezu mój, nie będę mogła dość głęboko zastanowić się nad Twoją dobrocią. Nigdy nie zdołam pojąć dobroci Twej - tak wielkiej, tak bezgranicznie wielkiej! Jaką ufność powinna ona we mnie obudzić, jaką świętą pewność, że mimo nędzy mojej zawsze na Ciebie liczyć, zawsze do Ciebie z ufnością zbliżać się mogę ${ }^{15}$.

W innym miejscu stwierdza:

Jezu mój, jaką ufność powinnam odczuwać, przypominając sobie Twoją dobroć! On mnie na pewno nie odrzuci, da mi niebo, bylebym żałowała, do win swych się przyznawała. Wpatrzona w Twój krzyż, nie dopuszczę nigdy, by do serca mego wkradł się brak ufności. Ufać chcę zawsze, mimo całej nędzy mojej, boś Ty samą miłością i dobrocią! ${ }^{16}$.

Dobroć Zbawiciela jest źródłem zaufania wobec Niego.

Ufność, o której pisze autorka Rozmyślań, jest przede wszystkim oparciem się na Chrystusie: „Chcę, o Jezu, zawsze na Tobie się opierać, a gardzić sobą, bo nic nie potrafię. Całą ufność pokładam w Tobie, Panie, boś Ty siłą moją i Ty możesz wszystko"17. Według św. Urszuli już samo wypowiadanie imienia Jezus powinno być aktem ufności i miłości: „O, rzućmy się do stóp Jezusa, tulmy się do Jego nóg i powtarzajmy z całą miłością, na jaką zdobyć się możemy: Jezu, Jezu, Jezu! Niech wymawianie tego świętego imienia będzie modlitwą miłości, ufności, wiary, oddania się Bogu na własność"18. Oparcie się z wiarą na osobie Jezusa i Jego obietnicach może wyrażać się w każdej modlitwie, także w tej najprostszej co do formy.

Zaufanie wobec Chrystusa wypływa z bliskiej, przyjacielskiej relacji z Nim. Autorka Rozmyślań podkreśla, że zażyłość ze Zbawicielem jest podstawą życia duchowego. Zaleca więc stawianie sobie następujących pytań podczas rachunku sumienia: „Czy Jezus jest serdecznym naszym

${ }^{13}$ Zob. J. Misiurek, Historia i teologia polskiej duchowości katolickiej, Lublin 2001, s. $147-155$.

${ }^{14}$ U. Ledóchowska, Rozmyślania, t. 1, I 4. 3.

15 Taż, Rozmyślania, t. 2, IX 14. 2.

16 Tamże, X 22. 2.

${ }_{17}$ U. Ledóchowska, Rozmyślania, t. 1, III/IV 9. 2.

18 Tamże, I 1. 2. 
Przyjacielem? Czy z całą ufnością do Niego się zwracamy, Jemu oddajemy swe trudności, krzyżyki, troski, a przede wszystkim swą wolę?" ${ }^{19}$. Jeżeli Chrystus jest dla człowieka kimś naprawdę bliskim, to relacja z Nim stanowi oparcie w różnych okolicznościach życia.

Matka Urszula bardzo często pisze o zupełnym oddaniu się w ręce Jezusa, które możliwe jest tylko wtedy, gdy Chrystus jest dla wierzącego prawdziwie najlepszym Przyjacielem:

Jezu, jeśli Ciebie naprawdę kocham, to powinnam oddać się zupełnie w Twe ręce, powinnam mieć jedno pragnienie - należeć do Ciebie, byś ze mną mógł czynić, co tylko Tobie się podoba. Powinnam zupełnie oddać Tobie, memu najlepszemu Przyjacielowi, swą wolę, prosząc, by zawsze Twoja wola we mnie się spełniała, bo Ty najlepiej mną pokierujesz ${ }^{20}$.

Powierzenie się Zbawicielowi jest również powodowane pragnieniem zjednoczenia swojej woli z wolą Bożą. Autorka Rozmyślań stwierdza:

Jezus wszystko wie, On moje życie, moją przyszłość ma w swoim ręku - jaki to dla mnie powód do ufności bez granic! Mogę być spokojna Jezus nade mną czuwa, przyszłość moją przygotował, w swoich tyczących się mnie rozporządzeniach stosuje się do moich sił, nie włoży na moje ramiona krzyża, który by mnie przygniótł, dodaje siły w trudnych chwilach, gdy widzi, żem bliska upadku. A ja nie miałabym ufać? Jezu mój, o wiele spokojniejsza mogę być, oddając się w ręce Twoje, niż gdybym sama sobą rządziła. Weź mnie, o Panie, zrób ze mną, co chcesz, jam Twoja na wieki. Tylko nigdy, mimo mojego buntu, nie wypuszczaj mnie $\mathrm{z}$ rąk Twoich, bo wtedy zginę! ${ }^{21}$.

Całkowite oddanie się w ręce Jezusa to dla św. Urszuli wyraz wiary i zaufania.

Pisząc o powierzaniu się człowieka wierzącego w ręce Chrystusa, święta Urszula odnosi się do relacji istniejących w Trójcy Świętej - wskazuje na miłość pomiędzy Bogiem Ojcem i Synem. Ewangeliczne zdanie: „Ojciec miłuje Syna i wszystko oddał w Jego ręce” (J 3,33) jest dla autorki Rozmyślań fragmentem, który rzuca światło na wzajemną

\footnotetext{
19 Tamże, XII 27. 2.

20 Tamże.

${ }^{21}$ U. Ledóchowska, Rozmyślania, t. 1, III/IV 66. 2.
} 
miłość Osób Boskich, a zarazem stanowi punkt wyjścia do refleksji nad implikacjami tego stwierdzenia w życiu człowieka. Matka Ledóchowska zauważa, zwracając się do sióstr: „Jaka to pocieszająca prawda: wszystko w ręku Twoim, Jezu! [...] Jestem, o Jezu, w dobrym, w pewnym ręku, nie potrzebuję się więc niepokoić, trapić, co będzie, co się ze mną, co się z naszym Zgromadzeniem, z naszymi domami dziać będzie"22. Pewność należenia do Chrystusa rodzi tym większe zaufanie:

Wszak my wszystkie jesteśmy w Twoim ręku i Ty nam krzywdy nie wyrządzisz, to pewne! Jaką błogą ufnością napełnia mnie ta myśl i jak powinnam zawsze trwać w niczym nienaruszonej ufności. Patrz, duszo moja, mała dziecina na ręku swej matki czuje się bezpieczna, niczego się nie lęka, bo wie, że matka kocha, czuwa nad nią, a w potrzebie obroni, a ja bym nie miała trwać w pokoju, wiedząc, żem w ręku Jezusa dobrego, który życie swe oddał, by mnie od wiecznego nieszczęścia obronić? ${ }^{23}$.

Świadomość pełnej troski miłości Zbawiciela jest podstawą zaufania Jezusowi.

Postawy, o których pisze święta Urszula, powinny znajdować swoje odzwierciedlenie w modlitwie. Człowiek, zwracający się o pomoc do Boga $w$ rozmaitych sprawach, zaproszony jest do oddawania się z wiarą i z ufnością w ręce Zbawiciela. Matka Ledóchowska pisze:

Potrzeba mi wiary, z której zarazem wypływa ta błoga ufność: na pewno, bylebym prosiła, Jezus da to, czego mi potrzeba. Da to, co będzie dla mego dobra, bez względu na to, czy to zgodne z moją wolą, czy też nie. Wszak moja wola to żądanie głupiego dziecka, które domaga się zabawy z ogniem lub brzytwą, a nie rozumie, że ogień pali, a brzytwa może je zranić. A czy w takim wypadku kochająca matka może pragnienie dziecka zadowolić? Tak, o Jezu, słodki mój Panie, z wiarą i ufnością oddaję się w ręce Twoje, wierząc, że mnie kochasz, że chcesz mego dobra, a ta myśl daje mi spokój i szczęście nawet w chwilach bólu i cierpienia, które przecież być muszą na tym łez padole ${ }^{24}$.

Zaufanie Jezusowi ma dla św. Urszuli wymiar eucharystyczny. Akcentuje ona niezastąpione znaczenie realnej obecności Chrystusa w Naj-

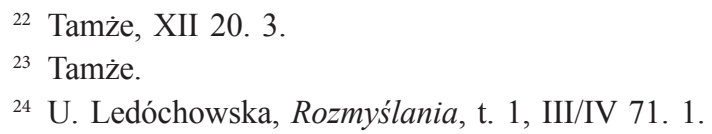


świętszym Sakramencie. Przekonuje: „Jezus w Tabernakulum to centrum, około którego całe życie moje powinno się obracać. Myśl moja wśród pracy i zajęć musi lecieć do Tabernakulum, a pamięć o Jezusie w Białej Hostii powinna mnie zachęcać do ufności, gdy troski przygniatają; do odwagi, gdy praca wydaje się nad siły"25. Matka Ledóchowska wskazuje, jak ważne jest, by pamiętać o obecności w tabernakulum Boskiego Przyjaciela, na którego można liczyć w każdej trudności, wiedząc, że On może i chce pomóc każdemu człowiekowi, który do Niego się zwraca. Autorka Rozmyślań poleca stawiać sobie pytanie: „Czy więc w chwilach ciężkich, w chwilach cierpienia, niepewności i trwogi udaję się do Niego z całą ufnością?”26. I dodaje: „O, bo Jezus tego chce i tego po mnie się spodziewa, bo Mu się podoba ta dziecięca, głęboka ufność! A czy nie mam zwyczaju naprzód szukać pomocy, pociechy u ludzi, a potem dopiero, gdy się na nich zawiodłam, uciekać się do Jezusa?"27. Święta Urszula pokazuje, jak ważna jest stała ufność, że Chrystus nigdy nie opuści, że zawsze gotów jest człowiekowi pomóc, że jest najpewniejszym Przyjacielem, który nigdy nie zrobi zawodu ${ }^{28}$. Autorka Rozmyślań przypomina, że Boski Przyjaciel czeka na każdego ukryty w tabernakulum, w Najświętszym Sakramencie i do Niego warto przychodzić z ufnością bez stawiania sobie granic. „Niech się nauczę z całą ufnością garnąć się do Ciebie, o Jezu ukryty w Tabernakulum"29 - modli się Matka.

Szczególnym źródłem ufności jest dla św. Urszuli Najświętsze Serce Jezusa: „Boskie Serce Jezusa, w Tobie pełnia miłości Bożej, nasz pokój i nasze szczęście, w Tobie miejsce ucieczki dla duszy opuszczonej, prześladowanej, złamanej cierpieniem, w Tobie raj duszy Ciebie kochającej, w Tobie nieustające źródło ufności” ${ }^{30}$. Matka Ledóchowska wyjaśnia, że ufność to hołd oddany dobroci Boskiego Serca Jezusa, i wyznaje: „ten hołd bezgranicznej mojej ufności chcę oddawać Tobie do ostatniej chwili mego życia" ${ }^{1}$. Serce Jezusa jest pełne miłości i miłosierdzia, dlatego też z ufnością i bez żadnej obawy odmowy, można Je prosić o najpo-

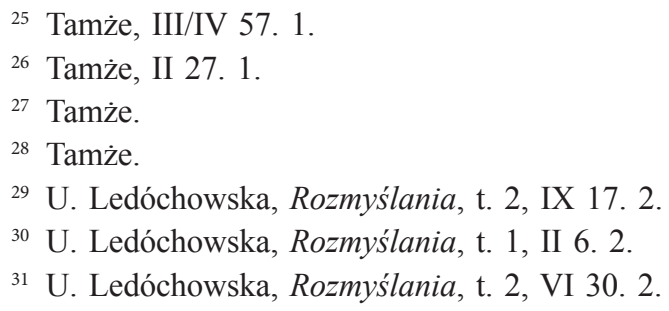


trzebniejsze łaski, wśród których najcenniejszą - według św. Urszuli jest miłość Boża, miłość ku Boskiemu Sercu Jezusowemu ${ }^{32}$. Autorka Rozmyślań pisze:

Serce Jezusa, mam ufność w Tobie! O, jak dobrze jest mieć kogoś, komu można w zupełności zaufać. Ale czy można całkowicie zaufać człowiekowi? Do pewnego stopnia tak, ale niezupełnie. Człowiek jest śmiertelny i nie jest wszechmocny; choćby chciał, nie zawsze może. A Serce Jezusa? Ono jest najlitościwsze i najbardziej kochające, a przy tym wszechmocne. Jakżeż Mu więc nie zaufać najzupełniej! Ufam, o Jezu, że Twoje Serce już mi przebaczyło grzechy przeszłości i tę przeszłość z całą ufnością rzucam w płomienie miłości Twego Boskiego Serca. Ufam, o Jezu, że mi dopomożesz w obecnych moich trudnościach i przeciwnościach. Kłopoty, troski, bóle, niepowodzenia - wszystko Tobie powierzam. Ty mnie uratujesz. Nie lękam się, boś Ty przy mnie! Ufam, że zaopiekujesz się mą przyszłością, tak doczesną, jak i wieczną. Nie chcę lękać się, choćbym znalazła się wśród cieniów śmierci, boś Ty, o Serce Jezusa, moją tarczą przeciwko wszelkim niebezpieczeństwom. Zawsze, zawsze chcę wołać wesoło: Serce Jezusa, mam ufność w Tobie! Serce Jezusa, wierzę w Twą miłość ku mnie! Wierzę w Twe Serce pełne miłości ku mnie, wierzę, że nikt na ziemi tak mnie nie kocha, jak Ty mnie kochasz, słodkie Serce Jezusa! Ta myśl jest tak pocieszająca. Dodaje ufności i siły biednej mojej duszy. Słodkie to jest uczucie - wiedzieć, że ktoś mnie bardzo kocha, że mogę liczyć na jego miłość ku mnie. A tu nawet cień podejrzenia nie może wślizgnąć się w mą duszę, jakoby Jezus mógł mnie opuścić33

Święta Urszula przekonuje, że Chrystus zawsze ma o każdego staranie, a zadaniem chrześcijanina jest ufne i spokojne spoczywanie w Sercu Zbawiciela. „On mną tym bardziej się zaopiekuje, im bardziej ja Nim będę zajęta” ${ }^{34}$ - stwierdza Matka, zachęcając siostry, by przez skupienie i milczenie trwały w Boskim Sercu Jezusa.

${ }^{32}$ Zob. tamże, VI 16. 3; W. Zyzak, Kontemplacja Krzyża jako centrum duchowości św. Urszuli Ledóchowskiej, w: „Otrzymała od Ducha Świętego wielki charyzmat”. Św. Urszula Ledóchowska i Urszulanki Serca Jezusa Konającego, red. M. Krupecka, W. Misztal, Kraków 2012, s. 81-83.

${ }^{33}$ U. Ledóchowska, Rozmyślania, t. 2, VI 12. 2-3.

${ }^{34}$ Tamże, VI 26. 3. 


\section{UFNOŚĆ W MIŁOSIERDZIE BOŻE}

Pisząc o ufności wobec Boga, św. Urszula akcentuje tajemnicę niepojętego i niezgłębionego miłosierdzia Bożego. Autorka Rozmyślań często podkreśla prawdę o grzeszności i słabości człowieka. Ponadto, przywołując słowa Księgi Psalmów, zaleca prosić Boga, by swój grzech zawsze mieć przed oczyma (zob. Ps 51,5), by nieustannie pamiętać o swej małości i nędzy względem Nieskończonego Boga. Dla Matki Ledóchowskiej pamięć ta nie prowadzi do rozpaczy, izolacji czy pogrążania się w smutku - przeciwnie: stała świadomość swej grzeszności i słabości ma tym bardziej skłaniać do powierzenia się w miłosierne ramiona Ojca Niebieskiego, który pragnie nawrócenia ze zła i daje łaskę do stawania się doskonałym, na wzór Jezusa. „Jam grzeszna, ale z ufnością tulę się do Ciebie; Ty przebaczysz, zapomnisz, pozwolisz mi kochać Ciebie i sam też kochać mnie będziesz!"35 - modli się autorka Rozmyślań. Przypomina i zapewnia, że człowiek boleśnie doświadczający swojej słabości i grzeszności, gdy tylko żałuje swych niegodziwości, może z całą ufnością uciekać się do Bożego miłosierdzia ${ }^{36}$.

„Im jestem gorsza, im mniejsza, im słabsza, tym bardziej z całą ufnością liczyć mogę na dobroć Jezusową i miłosierdzie Jego, bylebym z ufnością do Pana się zwracała" ${ }^{\prime 3}$ - stwierdza św. Urszula. Pokazuje zarazem, że podstawą pokoju każdej duszy jest żal za grzechy i ufność bez granic w miłosierdzie Boskiego Serca, a nie egoistyczne przekonanie o własnej bezgrzeszności i doskonałości. „Jakże nie żałować za grzechy, za najmniejsze przewinienia, gdy każdy z nich jest dowodem braku miłości, a przez to raną zadaną Boskiemu Sercu? A ja, o Jezu, tak bardzo chcę Ciebie kochać! Jakże nie mam ufać bez granic, gdy to Serce jest samą dobrocią i jednego pragnie - darować mi grzechy, przebaczyć, pojednać mnie z Ojcem Niebieskim, którego przez grzech obraziłam?"38 - pyta Matka Ledóchowska. Pisze ona również o „świętej nieufności wobec siebie”, wypływającej z pokory, rodzącej coraz większą ufność w Bogu

\footnotetext{
${ }^{35}$ U. Ledóchowska, Rozmyślania, t. 1, XII 18. 2.

${ }^{36}$ Zob. tamże, I 26. 3.

${ }^{37}$ U. Ledóchowska, Rozmyślania, t. 2, VII 14. 1.

38 Tamże, VI 28. 3.
} 
i przekonanie, że człowiek sam z siebie nic nie może, ale może wszystko w swoim Stwórcy i Odkupicielu ${ }^{39}$ :

O Jezu, daj mi zawsze pamiętać o swojej słabości, daj mi pamiętać o tym, że bez łaski Bożej jestem najnędzniejszym stworzeniem, zdolnym do wszystkich grzechów, że ciągle drżeć muszę na myśl o mojej nędzy, a tylko ufać miłosierdziu Bożemu. „Wszystko mogę w Tym, który mnie umacnia" (Flp 4,13) bez Niego nic nie potrafię, nic, tylko grzeszyć! O Jezu dobry, wspieraj mnie zawsze swą łaską, inaczej haniebnie upadnę. W uznaniu mojej nędzy, a w ufności w miłosierdzie Twoje jest siła moja! $!^{40}$.

Postawa ufności płynie z poznania miłosiernego Serca Pana Jezusa i wiary w Jego dobroć. Jako przykład takiego zaufania św. Urszula wskazuje dobrego łotra, modlącego się: „Panie, wspomnij na mnie, gdy przyjdziesz do swego królestwa” (Łk 23,42). Według autorki Rozmyślań, pokora i pokuta rodzą w sercu grzesznika dziecięcą ufność, dzięki której zwraca się on do Chrystusa $\mathrm{z}$ tą z pozoru zuchwałą prośbą. Rozważanie tego wydarzenia kończy się modlitwą: „O Jezu na krzyżu, naucz mnie naśladować dobrego łotra w jego pokorze i pokucie, a także w jego bezgranicznej ufności. Choćby grzechy moje były liczne jak piasek na brzegu morskim, choćby były czerwone jak szkarłat, staną się białe jak śnieg (zob. Iz 1,18), bylebym zawsze z ufnością pokuty i pokory udawała się do Jezusa na krzyżu"41. W Sercu Jezusa Konającego święta Urszula dostrzega źródło miłosierdzia, do którego zawsze może uciekać się grzesznik, żałujący za swoje przewinienia.

Według Matki Urszuli postawa zaufania wobec Boga i wiary w miłosierdzie Boże wyrasta na gruncie doświadczenia swojej słabości, na przekór pokusie ulegania lękowi, beznadziei i zamykania się w sobie. Autorka Rozmyślań zwraca uwagę, że człowiekowi przypatrującemu się swemu życiu i dostrzegającemu w nim wiele nieuporządkowania, grzechów, niewierności i niedoskonałości grozi poddanie się przejmującemu go strachowi. Może u niego pojawiać się lęk przed Sędzią i karą oraz

\footnotetext{
${ }^{39}$ Zob. U. Ledóchowska, Rozmyślania, t. 1, I 4. 2.

${ }^{40}$ Tamże, III/IV 18. 3

${ }^{41}$ Tamże, III/IV 43. 2.
} 
wątpliwość, czy zasługuje na miłosierdzie Boże. Święta Urszula zaleca wtedy właśnie spojrzeć na krzyż i usłyszeć słowa wypowiedziane przez Zbawiciela, odnoszące się do każdego człowieka: „Ojcze, przebacz im bo nie wiedzą, co czynią” (Łk 23,34). Chrystus nie narzuca się z miłosierdziem, ale chce je dać każdemu, tak jak ufającemu, dobremu łotrowi. Matka Ledóchowska więc wyznaje: „O Jezu, ufam, ufać nie przestanę, nie dla mej cnoty, bo jej nie mam, ale dla Twej dobroci, i w pokoju spocznę u stóp Twych dla mnie zranionych. Tyś mą ufnością i zawiedziona nie będę!" ${ }^{2}$. Pokazuje przez to, że najlepsze, co może zrobić wierzący, to klęknąć u zranionych stóp Jezusa i dziękować Mu za tak wielką miłość, która jest źródłem ufności, pokoju i prawdziwym wzorem do naśladowania ${ }^{43}$ :

O Jezu, jakżeś dobry, z jaką ufnością powinnam zbliżyć się do Ciebie, trwać przy Tobie mimo swej niegodności! Jednego mi potrzeba - uznania mej nędzy, zrozumienia mej niegodności i uczucia wdzięczności za to, że ten wielki Pan i Król mój chce mnie wezwać do siebie, na swą ucztę niebiańską tu, na ziemi, i do swego szczęścia w wieczności ${ }^{44}$.

Tym sposobem święta Urszula zachęca do stawania w pokorze i prawdzie wobec siebie, Boga i bliźnich.

Dynamika grzechu, dynamika zaufania miłosierdziu Bożemu i przebaczenia pokazana jest przez autorkę Rozmyślań w komentarzu do sceny zdrady i zaparcia się Piotra (Łk 22,59-62). Według Ewangelii apostoł trzykrotnie wyrzekł i wyparł się Jezusa, zanegował nawet znajomość z Nim. Święta Urszula zauważa, że gdy pierwszy raz upadł, mogło to stać się za sprawą braku namysłu, refleksji, ale za drugim razem, a szczególnie za trzecim - był to jego świadomy i dobrowolny wybór. W tej właśnie sytuacji Piotr został obdarowany miłosiernym spojrzeniem Jezusa, którego wzrok, pełen miłości i „słodkiego wyrzutu, jakby mieczem przebił serce Piotra”45. Uczeń zobaczył swoją niegodziwość, zrozumiał swój upadek i zrodziła się w nim szczera skrucha, a „cała miłość ku Jezusowi zapłonęła

\footnotetext{
${ }^{42}$ Tamże, III/IV 42. 2.

${ }^{43}$ Zob. tamże, III/IV 42. 1.

${ }^{44}$ Tamże, III/IV 5. 1.

${ }_{45}$ Tamże, III/IV 19. 2.
} 
w sercu apostoła na nowo" ${ }^{46}$. W takiej perspektywie wiary w miłosierdzie Boże, Matka Ledóchowska zwraca uwagę na znaczenie spojrzenia Zbawiciela, które ma moc przemienić człowieka: „O siło i mocy wzroku Chrystusowego! Jedno Twoje spojrzenie, o Jezu, i serce Piotra odwraca się od grzechu, a skruszone i uniżone wraca do Ciebie" ${ }^{47}$. Święta Urszula, medytując to wydarzenie, doprowadza czytelnika Rozmyślań do modlitewnego zwrócenia się do Chrystusa:

Spojrzyj, Jezu dobry, i na mnie. Zwróć ku mnie swe miłosierne oczy, niech wzruszą i moje twarde serce, odciągną je od złego, napełnią miłością. Popatrz, Jezu, na mnie tak, bym zawsze czuła ten Twój Boski, pełen miłości wzrok skierowany ku sobie, by i cała dusza moja do niego się zwróciła, bym go czuła, gdy się modlę, gdy pracuję, bym pod Twoim wzrokiem pracę swoją jak najsumienniej wykonała. Niech go czuję w rozterce wewnętrznej, w wątpliwościach, by wówczas wzrok Twój był dla mnie światłością, rozjaśniającą ciemności mojego umysłu. Niech go czuję $\mathrm{w}$ radości, by i radość moja była zawsze rozjaśniona tym światłem, płynącym $\mathrm{z}$ góry, by nawet $\mathrm{w}$ pociechach ziemskich duch mój zawsze rozradował się w Bogu, Zbawicielu moim. Spraw, bym czuła Twój wzrok, pełen litości i miłosierdzia, spoczywający na mnie, gdy będę uginała się pod ciężarem krzyża, abym w tych ciężkich chwilach nie traciła ani odwagi, ani ufności, ale pod wpływem Boskiego Twego wzroku przepełniona była radością we wszystkich cierpieniach (zob. 2 Kor 1, 4; Kol 1, 24) i przeciwnościach moich ${ }^{48}$.

Umiejętność dostrzegania miłosiernego spojrzenia Jezusa, zwłaszcza w chwilach upadku, grzechu i słabości, rodzi ufność w miłosierdzie Boże, którego potrzebuje każdy człowiek.

\section{ZAUFANIE W TRUDNYCH CHWILACH}

Zaufanie Bogu jest postawą, do której chrześcijanin jest wezwany we wszystkich okolicznościach. Matka Ledóchowska w Rozmyślaniach zwraca szczególną uwagę na te sytuacje w życiu człowieka, kiedy ufność

\footnotetext{
46 Tamże.

47 Tamże.

48 Tamże.
} 
wobec Boga staje się wyzwaniem czy poddana jest próbie. Może to mieć miejsce wówczas, gdy wierzący doświadcza trudności, wewnętrznych czy zewnętrznych, gdy staje bezradny wobec problemów, gdy odczuwa lęk, niepewność i zamieszanie, gdy trapią go wątpliwości i różnego rodzaju ciemności, gdy obawia się o przyszłość. Święta Urszula podpowiada, co należy czynić w takich momentach: „Iść naprzód, zawsze odważnie, zawsze z ufnością. Bóg tak chce”49. I dodaje, zwracając się do sióstr: „Wszak my w zakonie jesteśmy szczęśliwe, bo zawsze wiemy, którą drogą mamy iść i dokąd dążyć. Byleby móc sobie powiedzieć: to droga, którą Bóg dla mnie wybrał - to choćby ona była straszna, ciemna, pełna niebezpieczeństw, nie powinnam na to zważać. Bóg z nami, On dopomoże, doprowadzi, On najpewniejszym przewodnikiem. Naprzód!"50. Zabieganie o pełnienie woli Bożej powinno cechować każdego chrześcijanina. Nawet w najtrudniejszych chwilach oraz warunkach wierzący nie powinien tracić zaufania wobec Boga i pokoju serca, który płynie z przekonania, że wypełnia to, czego Bóg oczekuje od niego. Zaufanie łączy się więc z umiejętnością wytrwałego i cierpliwego oczekiwania, które oznacza pozostawanie na swoim miejscu z Bogiem i przeżywanie teraźniejszości z wiarą, że ujawni ona to, co jeszcze jest ukryte. Takie zaufanie jest więc aktywne, jest pełną obecnością osoby przed Bogiem, zawiera w sobie przekonanie, że ten właśnie trudny moment ma swoje niezastąpione znaczenie według zamysłu Bożego.

Człowiek, który ufa Bogu i wybiera Jego wolę, nie zawsze jest zdolny uniknąć trudnych uczuć i emocji. Natura ludzka ma swoje prawa, nie ulega ona automatyzmowi. Dlatego zdaniem świętej Urszuli „strach, niepokój może iść w parze z największą ufnością"51. Wierzący może dokładać starań, by jednoczyć swoją wolę z wolą Bożą, lecz nie jest w stanie szybko zmienić swoich przemijających odczuć. Matka Ledóchowska zachęca, by - niezależnie od kondycji psychicznej - wołać do Zbawiciela, prosić Go $\mathrm{z}$,tą pogodną ufnością, która nie tylko ufa, ale wie, że na pewno Jezus dopomoże i wyratuje; która choć otoczona czarnymi chmurami, raduje

\footnotetext{
${ }^{49}$ U. Ledóchowska, Rozmyślania, t. 1, I 16. 1.

50 Tamże.

51 Tamże.
} 
się jasnym słońcem, świecącym zawsze tam na górze" ${ }^{52}$. Według autorki Rozmyślań wytrwała ufność ma moc wzruszyć Serce Jezusa. Przekonuje więc ona:

Tylko Jezus może skutecznie podać mi rękę i poprowadzić mnie bezpiecznie drogą zbawienia, tylko Jezus jest Pośrednikiem między człowiekiem i Bogiem. Toteż do Niego mam się uciekać, do Niego wołać nieustannie, coraz natarczywiej, coraz goręcej, choćby mi się wydawało, że Jezus nie słyszy. Wołać, wołać, nigdy się nie zniechęcając, nigdy nie tracąc ufności. I nie zważać na to, co ludzie mówią. Niech łają, niech się wyśmiewają, starając się mnie od Jezusa oddalić, niech gardzą za wierne wołanie do Jezusa. Cóż mnie zdanie świata obchodzi? O Jezu, chcę w Tobie ufność swą pokładać. Jam nędzna, wiem o tym, jam ślepa, bo Ciebie nie widzę. Nieraz zdaje mi się, żem od Ciebie tak daleko, ale i tym nie chcę się niepokoić. Nieraz wokoło mnie ciemno, zupełnie ciemno, drogi swej już nie widzę. Niech to mi nie odbiera spokoju. Bylebym do Ciebie wołać nie przestała ${ }^{53}$.

Autorka Rozmyślań zachęca więc do wytrwałej modlitwy ufności, bez względu na okoliczności życia i niezależnie od reakcji innych osób. Przypomina, by nie zniechęcać się trudnościami. Człowiek pełen zaufania Bogu jest otwarty i gotowy na to, że mogą zdarzyć się rzeczy, które zdecydowanie przekraczają jego osobiste wyobrażenia. Potrafi zrezygnować z chęci zapanowania nad przyszłością, i zgadza się na Boże rozwiązania odnoszące się do życia. Wierzy bowiem, że Bóg ukształtuje przyszłość zgodnie z Jego miłością.

Matka Urszula zastrzega zarazem, że postawa ufności i oparcia się na Chrystusie nie powinna czynić człowieka biernym i leniwym. Zaufanie Bogu nie zwalnia wierzącego z zaangażowania, lecz odgrywa niezastąpioną rolę w życiu doczesnym - nie odrywa wzroku człowieka od świata, nie wiedzie do ucieczki od niego, przenosząc myślą do wyimaginowanego nieba: zobowiązuje zaś do pełnego zaangażowania się w sprawy ziemskie, nie skłania do apatycznej bezczynności, nie dyspensuje człowieka z odpowiedzialności za ten świat, ale pogłębia ją i umacnia. Autorka Rozmyślań stwierdza: „Ufność w pomoc Jezusa nie powinna nas czynić

${ }^{52}$ U. Ledóchowska, Rozmyślania, t. 2, VII 13. 2.

${ }^{53}$ Tamże, VIII 21. 2. 
leniwymi. Jezus dopomoże, ale z naszej strony żąda pracy. Pracy, gdy chodzi o uświęcenie naszej duszy - trzeba więc modlić się, ale jednocześnie nad sobą pracować. Pracy domaga się Jezus, gdy chodzi o dobro innych dusz, o uczynki miłosierdzia" ${ }^{54}$. Zaufanie Bogu to podstawa i fundament aktywności i właściwego zaangażowania człowieka. Podejmowanie działań jest wyrazem ufności pokładanej w Bogu, ponieważ prawdziwe zaufanie przynagla do dobrego czynu, wyrywa ze złudnego spokoju i nie pozwala na bezradną bezczynność, w której brak miłości.

Święta Urszula patrzy realnie na człowieka i rzeczywistość, w której on się znajduje. Przede wszystkim nie zaprzecza prawdzie o słabości i grzeszności człowieka oraz nie neguje trudności i problemów, z którymi musi się on zmagać. Pokazuje natomiast kierunek postępowania, mający zawsze za punkt wyjścia zwrócenie się do Zbawiciela: „Do Ciebie zawsze z ufnością przystąpić możemy i choćby wszyscy nas opuścili, Ty nas nigdy nie odrzucisz. Choćbyśmy nawet strasznie zawinili, Ty nas nigdy nie odepchniesz, zawsze przyjmiesz i zawsze to biedne, nędzne serce ludzkie przytulisz do Boskiego Serca swego" ${ }^{55}$. Wierzący nigdy nie może tracić nadziei. Patrząc z perspektywy wiary, wszystko ma znaczenie i sens w Bogu, nawet gdy człowiek nie pojmuje, w jaki sposób urzeczywistnia się zbawczy plan Boga. Matka Urszula stwierdza: „sama z siebie jestem tylko słabością, że nic nie umiem, nic nie potrafię, żem nicością do niczego niezdolną, a mimo to jednak powinnam mieć ufność w Bogu, który mocen jest dać mi łaskę, światło, siły, zrozumienie dróg Bożych" ${ }^{56}$. Słabość i grzeszność osoby ludzkiej same w sobie nie są przeszkodami dla działania Bożego.

W tym kontekście autorka Rozmyślań przestrzega przede wszystkim przed rozpaczą i nieufnością, które najbardziej ranią Serce Jezusa. „O, jak boleć musi Serce Boże, gdy widzi w oczach otaczających Go tyle niechęci, lekceważenia, nieufności, a przede wszystkim tyle złej woli” ${ }^{57}$ - stwierdza Matka Ledóchowska. Pokazuje, że Chrystus pragnie od człowieka wiary i ufności ${ }^{58}$, która najbardziej sprawdza się w chwilach próby i w trudnych wydarzeniach, gdy to, co było przedmiotem ludzkich oczekiwań,

\footnotetext{
54 Tamże, VII 14. 2.

55 Tamże, VII 32. 1.

${ }^{56}$ U. Ledóchowska, Rozmyślania, t. 1, V 2. 1.

57 Tamże, II 14. 2.

${ }^{58}$ Zob. U. Ledóchowska, Rozmyślania, t. 2, VIII 10. 2.
} 
załamuje się. Prawdziwe zaufanie Bogu pełni zarazem rolę demaskującą wobec jedynie naturalnego optymizmu czy pozytywnego nastawienia. Natomiast wtedy, kiedy brakuje ufności Bogu, może w kryzysie pojawić się zamykająca osobę rozpacz, o której święta Urszula pisze następująco:

Wielkim złem jest grzech, ale jeszcze większym rozpacz, bo z grzechu można powstać, można odpokutować, a nieraz nawet grzech stał się podwaliną świętości. Ale rozpacz nigdy dobrych owoców nie wydaje, bo rozpacz wyklucza ten cichy, słodki, miłości pełen żal, dziecięcą ufność, która jest tym piękniejsza, tym więcej wzrusza Serce Boże, im większy był grzech. O nigdy, nigdy nie dopuśćmy do serca naszego nie tylko rozpaczy, ale nawet nieufności. Ufajmy zawsze. Im jesteśmy nędzniejsze, z tym większą ufnością wołajmy: Jezusie, Mistrzu, Przyjacielu nasz, ratuj, bo zginiemy! (zob. Mt 8,25 ). I Jezus na pewno nas wyratuje ${ }^{59}$.

Na ewangelicznym przykładzie Judasza święta Urszula pokazuje, do czego może doprowadzić człowieka rozpacz i jak wielkim grzechem jest brak ufności. Świadomość, do jakiego zaślepienia zdolny jest człowiek, prowadzi ją do prośby skierowanej do Chrystusa: „O Jezu, nigdy, nigdy niech Cię nie obrażę brakiem ufności. Choćbyś mnie zabił, jeszcze w Tobie ufać będę, bo wiem, że mnie nigdy nie opuścisz!”60. Zaufanie Bogu otwiera na możliwość twórczej przemiany; uznaje, że czas i przestrzeń nie są zamknięte, że nie wszystko jest zdeterminowane, wyznaczone i określone horyzontami, jakie przedstawia ludzkiego ego.

Matka Ledóchowska pokazuje niezastąpioną rolę postawy ufności w godzinie śmierci człowieka. Chwila odejścia z tego świata w sposób nieunikniony rodzi strach i niepewność. Autorka Rozmyślań nie ucieka przed świadomością nieuchronnego rozstania się z ziemską rzeczywistością, które czeka każdego; przeciwnie - zaleca, by już w obecnym czasie, niezależnie od tego, na jakim etapie życia ktoś się znajduje, przygotowywać się do tego momentu. „A gdy nadejdzie śmierć, śmierć i wieczność, przed którą czuję lęk, to u stóp krzyża nauczę się z ufnością oddawać ducha swego w ręce najlepszego Ojca, tak jak to uczynił Jezus, wzór mój”' ${ }^{61}$ - pisze

\footnotetext{
59 Tamże, VIII 6. 2.

${ }^{60}$ U. Ledóchowska, Rozmyślania, t. 1, III/IV 23. 2.

${ }^{61}$ Tamże, III/IV 52.
} 
święta Urszula, zachęcając do kontemplacji Chrystusa, przyjmującego swą śmierć. Dodatkowo zaleca częste przywoływanie prawdy o znikomości rzeczy tego świata i szczęścia ziemskiego oraz krótkotrwałości cierpienia: „Cóż to wobec wieczności - te słowa świętego Alojzego, przeciwstawiane naszym krzyżykom i trudnościom, napełniają serce spokojem, ufnością, cierpliwością i odwagą. Cenić, co wieczne, gardzić tym, co przemijające - oto prawdziwa Boża mądrość"62. Rozważanie wiecznej radości w niebie i życie gorącym pragnieniem zjednoczenia z Bogiem jest wyrazem zaufania Wszechmocnemu i Jego obietnicom.

\section{ZAKOŃCZENIE}

Z analizy dzieła Rozmyślania świętej Urszuli Ledóchowskiej wynika, że jest ono nie tylko wypełnione refleksjami dotyczącymi ufności pokładanej w Bogu, lecz także stanowi świadectwo postawy zawierzenia Jemu. Zawiera również wiele modlitw, które wyrażają zaufanie Jezusowi Chrystusowi i są powierzaniem się w Jego ręce, zwłaszcza w trudnych chwilach, w głębokim przekonaniu o Jego miłości, dobroci i trosce. Święta Urszula wskazuje, że właściwa modlitwa, prawdziwe rozmyślanie - oprócz żalu za grzechy, uniżenia, miłości, zgadzania się z wolą Bożą - powinno prowadzić właśnie do ufności w Bogu ${ }^{63}$.

Ufność pokładana w Bogu - według Matki Ledóchowskiej - wypływa ze świadomości bycia umiłowanym przez Stwórcę; jest cechą charakterystyczną tego, kto żyje w pełni swą godnością dziecka Bożego. Ponadto, człowiek dostrzegający swoją grzeszność, słabość i okazujący skruchę z powodu swych nieprawości, może z całą ufnością uciekać się do Bożego miłosierdzia. Co więcej, im bardziej ktoś jest przekonany o swej małości i nicości, z tym większą ufnością może liczyć na miłosierdzie Pana. Autorka Rozmyślań - której duchowość cechuje się chrystocentryzmem - akcentuje postawę zwracania się do Jezusa z całkowitym powierzaniem się w Jego ręce. Postawa ta adekwatnie wyrażona jest $\mathrm{w}$ następującej modlitwie:

\footnotetext{
${ }^{62}$ Tamże, V 29. 1.

${ }^{63}$ Tamże, s. 8.
} 
O Jezu, [...] pójdę za Tobą, dokąd zechcesz mnie zaprowadzić, zamykam oczy, a Ty prowadź. I czy powiedziesz po drodze gładkiej, równej, czy po ścieżce stromej i skalistej, czy w jasności wiosennego poranku, czy w ciemności nocy - ja zawsze pójdę za Tobą i bać się nie będę, bylebyś Ty, Panie, był przy mnie! Prowadź! Ale Ty znasz moją słabość, więc daj odwagę, daj męstwo, a gdy ujrzysz, że słabnę, że siły mnie opuszczają, wyciągnij swą wszechmocną rękę i dźwignij duszę z upadku ${ }^{64}$.

Zaufanie Chrystusowi jest niezbędne zwłaszcza w trudnościach i przeciwnościach.

Rozważania Matki Urszuli, zawarte w analizowanym dziele, powstały z jej pragnienia, by wesprzeć siostry urszulanki w modlitwie słowem Bożym, a tym samym, by pomóc im w budowaniu zażyłej, trwałej i pełnej zaufania relacji z Chrystusem. Ponadto należy stwierdzić, że to, co autorka Rozmyślań pisze o postawie ufności, może być odniesione nie tylko do osób poświęconych Bogu na własność, lecz do wszystkich wierzących. Matka Urszula ukazuje bowiem, że autentyczne życie chrześcijańskie jest świadectwem ufności zakorzenionej w Chrystusie. Człowiek ochrzczony nie ulega rozpaczy ani nie poddaje się nieufności, nawet w najtrudniejszych chwilach życia. Jest powołany do zaufania Zbawicielowi i do otwierania się na to, aby dzięki mocy pokładanej w Bogu wraz z Nim przezwyciężać beznadziejność, nie zniechęcać się w żadnych okolicznościach i uznać, że przyszłość może okazać się inna niż się przypuszcza.

\section{BIBLIOGRAFIA}

Ledóchowska U., Rozmyślania dla Sióstr Urszulanek Serca Jezusa Konającego, t. 1, Pniewy 2000.

Ledóchowska U., Rozmyślania dla Sióstr Urszulanek Serca Jezusa Konającego, t. 2, Pniewy 2000.

Leksykon duchowości katolickiej, red. M. Chmielewski, Lublin-Kraków 2002.

Misiurek J., Historia i teologia polskiej duchowości katolickiej, t. 3, Lublin 2001.

„Otrzymała od Ducha Świętego wielki charyzmat”. Św. Urszula Ledóchowska i Urszulanki Serca Jezusa Konającego, red. M. Krupecka, W. Misztal, Kraków 2012.

Pagacz M., Pokora w „Rozmyślaniach” św. Urszuli Ledóchowskiej w świetle „Ćwiczeń duchowych” św. Ignacego Loyoli, „Studia Bobolanum” 2 (2019), s. 65-82.

${ }^{64}$ Tamże, III/IV 70. 3. 
Zyzak W., Kontemplacja Krzyża jako centrum duchowości św. Urszuli Ledóchowskiej, w: „Otrzymała od Ducha Świętego wielki charyzmat”. Św. Urszula Ledóchowska i Urszulanki Serca Jezusa Konającego, red. M. Krupecka, W. Misztal, Kraków 2012, s. 73-94. 